\title{
Pengaruh Kualifikasi Pendidikan, Pengalaman dan Disiplin Kerja Terhadap Kinerja Guru Di SMA Frater Makassar
}

\author{
Basri Bado $^{1^{*}}$, Revoluance Adimuntja ${ }^{2}$ \\ ${ }^{1}$ Fakultas Ekonomi Universitas Negeri Makassar, \\ ${ }^{2}$ Mahasiswa Program Program Pasca Sarjana, Universitas Negeri Makassar, \\ 1Email: basri.bado@unm.ac.id; ${ }^{2}$ Email: epoyadimuntja@gmail.com
}

(Received: 10 Februari 2021; Accepted: 15 April 2021; Published: 30 Juli 2021)

\begin{abstract}
The research used a quantitative approach with the aim of being able to identify and analyze the effect of educational qualifications, work experience and work discipline on teacher performance at SMA Frater Makassar. The research method used was a survey with a sample size of 41 teachers. The sampling technique used a saturated sample technique, namely that the entire population was used as the research sample. Collecting data using questionnaires, observation and documentation techniques. The data analysis method used was validity test, reliability test and spearman rank correlation test. The data analysis technique used is descriptive analysis (average score, standard deviation, variance and percentage), classical assumption test (normality test, linearity test, multicollinearity test, heteroscedasticity test) multiple regression test, t-test, f-test and determination coefficient delta test $(\Delta \mathrm{R} 2)$. The results showed that educational qualifications, work experience and work discipline simultaneously affect teacher performance, the amount of influence given is $24.2 \%$, while the remaining $75.8 \%$ is explained or influenced by other variables not selected in this study.
\end{abstract}

Keywords: Education Qualifications; Work Experience; Work Discipline; Teacher Performance

\section{PENDAHULUAN}

Pendidik adalah tenaga kependidikan yang berkualifikasi sebagai guru, dosen, konselor, pamong belajar, widyaiswara, tutor, instruktur, fasilitator, dan sebutan lain yang sesuai dengan kekhususannya, serta berpartisipasi dalam menyelenggarakan pendidikan. Guru sebagai salah satu tenaga pendidik tentu mempunyai peran penting untuk meningkatkan kualitas pendidikan. Guru dalam melaksanakan tugas pokok dan fungsinya sangat membutuhkan pengembangan diri. Sumber daya manusia khususnya Guru dalam pendidikan sangat penting untuk meningkatkan kualitas program pendidikan sesuai dengan undangundang.

Guru sebagai ujung tombak dalam meningkatkan mutu pendidikan perlu meningkatkan kinerja mereka. Kinerja Guru mempunyai kedudukan yang penting dalam peningkatan dan pengendalian mutu pendidikan. Ada beberapa hal yang dapat mempengaruhi kinerja seorang guru menurut Mulyasa (2004:139), antara lain: (1) sikap mental berupa motivasi, disiplin, dan etika kerja, (2) tingkat pendidikan, (3) keterampilan, mencakup kecakapan (ability) dan pengalaman (experience), (4) manajemen, (5) hubungan industrial, (6) tingkat penghasilan, (7) gizi dan kesehatan, (8) jaminan sosial, (9) lingkungan, (10) kualitas sistem, (11) teknologi yang dipakai, dan (12) kesempatan berprestasi.

Seorang guru harus memiliki tanggung jawab yang tinggi, totalitas dalam bekerja, meningkatkan keahliannya dalam mengajar dan menyukai tantangan. Melalui pengalaman kerja seorang guru jauh lebih pandai mengambil keputusan saat menghadapi sebuah masalah dibandingkan dengan guru yang memiliki pengalaman kerja yang kurang.

Pengalaman kerja merupakan suatu bagian yang penting dalam proses pengembangan keahlian seseorang. Tetapi hal tersebut juga tergantung pada pendidikan serta latihan. Pengalaman serta latihan ini akan diperoleh melalui suatu masa kerja. Melalui pengalaman kerja tersebut seseorang secara sadar atau tidak sadar belajar, sehingga akhirnya dia akan memiliki kecakapan teknis, serta keterampilan dalam menghadapi pekerjaan. Melalui 
pengalaman kerja dan tingkat pendidikan yang dimiliki oleh guru, maka guru akan lebih mudah dalam menyelesaikan setiap pekerjaan yang dibebankan.

Kualifikasi pendidikan merupakan skor kecenderungan kemampuan seorang Guru untuk memperoleh keahlian melalui tingkat atau jenjang pendidikan formal, non formal dan informaluntuk mengembangkan perannya dan mencapai tujuan yang berkualitas. Pengalaman kerja merupakan skor kecenderungan proses pembentukan pengetahuan berupa kualitas Guru dalam melaksanakan tugas yang sangat menentukan keberhasilan pendidikan yang dapat diukur melalui indikator pendidikan dan pelatihan, masa mengajar/masa kerja, dan kesempatan kerja.

Disiplin kerja merupakan skor kecenderungan proses pembentukan pengetahuan berupa kualitas Guru dalam melaksanakan tugas yang sangat menentukan keberhasilan pendidikan yang dapat diukur melalui indikator teladan pemimpin, balas jasa, keadilan, ketegasan, dan hubungan kemanusiaan.

Disiplin kerja merupakan salah satu faktor yang dapat mempengaruhi kinerja seorang guru. Disiplin kerja merupakan suatu sikap, perbuatan untuk selalu menaati tata tertib. Disiplin kerja dapat diartikan sebagai pelaksanaan manajemen untuk memperteguh pedoman-pedoman organisasi. Disiplin kerja guru merupakan sikap pengendalian diri seorang guru yang bersedia menaati aturan yang berlaku baik yang tertulis maupun tidak tertulis dilingkungan sekolah dan bersedia menerima sanksi apabila melakukan kesalahan.

Pembentukan tingkah laku atau karakter yang sesuai dengan yang diharapkan dapat menggunakan kedisiplinan. Seorang guru yang memiliki kesadaran kedisiplinan tinggi maka ia telah sadar akan tanggung jawab terhadap pekerjaan sehingga akan terwujud efisiensi dan efektifitas kerja yang berujung pada tujuan yang telah ditetapkan.

Kinerja Guru merupakan skor kecenderungan hasil kerja Guru yang dicapai dalam melaksanakan tugas sesuai dengan wewenang dan tanggungjawab dalam mencapai tujuan yang dapat diukur melalui indikator perencanaan dan pelaksanaan pembelajaran, kedisiplinan kerja, dan kemampuan bekerja sama.

Sebagai bagian dari proses peningkatan kualitas Pendidikan, maka perlu dilakukan penelitian yang bertujuan untuk mengetahui Pengaruh Kualifikasi Pendidikan, Pengalaman
Kerja dan Disiplin Kerja terhadap Kinerja Guru di SMA Frater Makassar.

\section{METODE}

Penelitian ini menggunakan jenis penelitian kuantitatif dengan metode deskriptif kuantitatif. Desain penelitian yang akan digunakan adalah ex-post facto. Variabel dalam penelitian ini terdiri dari 3 variabel independen yaitu kualifikasi pendidikan, pengalaman kerja dan disiplin kerja dan 1 variabel dependen yaitu kinerja guru. Lokasi penelitian ini adalah di SMA Frater Makassar. Tempat ini dipilih sebagai lokus penelitian karena sesuai dengan permasalahan yang diteliti. Desain penelitian dapat dilihat pada gambar 1 dibawah ini:

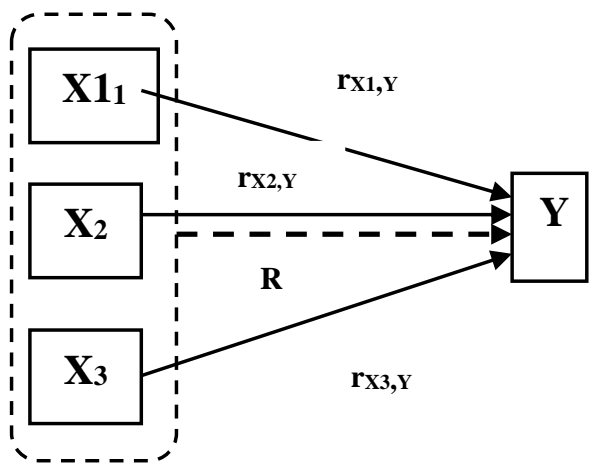

Gambar 1. Desain Penelitian

Keterangan:

$\mathrm{X}_{1}=$ Kualifikasi Pendidikan

$\mathrm{X}_{2}=$ Pengalaman kerja

$\mathrm{X}_{3}=$ Disiplin Kerja

$\mathrm{Y}=$ Kinerja Guru

Populasi dalam penelitian ini adalah seluruh guru yang ada di SMA Farater Makassar yaitu 41 guru dan seluruh jumlah populasi dijadikan sampel. Teknik penarikan sampel jenuh digunakan apabila jumlah populasi yang ada dianggap sedikit. Penelitian ini terdiri dari 3 variabel bebas yaitu kualifikasi pendidikan, pengalaman kerja dan disiplin kerja serta 1 variabel terikat yaitu kinerja guru. Variabel dalam penelitian ini diukur dengan menggunakan skala likert. Tehnik pengumpulan data dalam penelitian ini terdiri dari: kuesioner atau angket, dokumentasi, dan observasi. Sedangkan instrument penelitian yang digunakan dalam penelitian ini adalah uji validitas, uji reliabilitas dan uji korelasi spearman rank. Tehnik analisis data menggunakan tehnik analisis deskriptif yang terdiri dari skor rata-rata (mean), simpangan baku, varians serta presentase). Uji asumsi klasik 
(uji normalitas, uji linieritas, uji multikolinieritas dan uji heteroskedastisitas). Pengujian hipotesis dilakukan dengan menggunakan uji regresi berganda, uji t, dan uji f serta uji delta koefisien determinasi $(\Delta \mathrm{R} 2)$.

\section{HASIL DAN PEMBAHASAN}

a) Uji Validitas

Berdasarkan hasil uji validitas diperoleh bahwa semua item pada kualifikasi Pendidikan (X1), Pengalaman Kerja (X2) dan Kinerja Guru (Y) dinyatakan valid (Tabel terlampir). Hal tersebut dibuktikan bahwa semua item pernyataan lebih besar dari nilai r-tabel 0.308 dengan demikian dapat disimpulkan bahwa semua item pernyataan pada variabel $\mathrm{X}_{1}, \mathrm{X}_{2}, \mathrm{X}_{3}$ dan $\mathrm{Y}$ dinyakan valid dan layak digunakan.

b) Uji Reliabilitas

Pengujian reliabilitas pada penelitian ini menggunakan aplikasi aplikasi SPSS dan ditemukan terhadap item-item pernyataan pada variabel $\mathrm{X}_{1}$ (kualifikasi pendidikan), $\mathrm{X}_{2}$ (pengalaman kerja) $\mathrm{X}_{3}$ (Disiplin kerja) dan $\mathrm{Y}$ (kinerja guru) menunjukkan koefisien. Cronbach's Alpha lebih besar dari standar cronbach alpha $\mathbf{0 . 7}$, hal tersebut membuktikan bahwa item-item pernyataan yang digunakan dapat disimpulkan reliabel atau dapat dipercaya sebagai alat pengumpul data dalam penelitian.

c) Uji Korelasi Spearman Rank

Berdasarkan hasil olah data uji korelasi pada tabel Spearman Rank Correlations diperoleh nilai korelasi koefisien untuk hubungan variabel kualifikasi pendidikan $\left(\mathrm{X}_{1}\right)$ terhadap variabel kinerja guru $(\mathrm{Y})$ adalah sebesar $0.739^{* *}$ dengan tanda positif signifikan pada tingkat kepercayaan 95\%. Hal tersebut menunjukkan bahwa kualifikasi pendidikan memiliki hubungan yang positif serta tingkat hubungan kuat dengan kinerja guru, dimana koefisen variabel kualifikasi pendidikan berada pada interval 0,60-0,799 sesuai dengan interpretasi kuatnya hubungan korelasi menurut Sugiyono (2014).

Selanjutnya, diketahui nilai korelasi koefisien untuk hubungan variabel pengalaman kerja $\left(\mathrm{X}_{2}\right)$ terhadap variabel kinerja guru $(\mathrm{Y})$ adalah sebesar 0.655 . dengan tanda positif signifikan pada tingkat kepercayaan 95\%. Hal tersebut menunjukkan bahwa pengalaman kerja memiliki hubungan yang positif serta tingkat hubungan kuat dengan kinerja guru, dimana koefisen variabel pengalaman kerja berada pada interval 0,60 - 0,799. Sedangkan untuk nilai korelasi antara disiplin kerja dengan kinerja guru adalah 0.757. Nilai koefisien korelasi antara variabel disiplin kerja dengan kinerja guru 0.757 , dengan tanda positif signifikan pada tingkat kepercayaan 95\%. Hal tersebut menunjukkan bahwa disiplin kerja memiliki hubungan yang positif serta tingkat hubungan kuat dengan kinerja guru, dimana koefisen variabel disiplin kerja berada pada interval $0,60-0,799$ sesuai dengan interpretasi kuatnya hubungan korelasi menurut Sugiyono (2014).

d) Pengujian Hipotesis (Uji Regresi Berganda, Uji-T, Uji-F). dan

- Uji Regresi Berganda

Tabel 1. Uji Regresi Berganda

\begin{tabular}{lcc}
\hline Variabel & Nilai Konstanta & Nilai Standar Eror \\
\hline Kinerja Guru & 21.811 & 16.761 \\
Kualifikasi Pendidikan & .540 & .176 \\
Pengalaman Kerja & .166 & .115 \\
Disiplin Kerja & .080 & .126 \\
\hline
\end{tabular}

Sumber: Hasil olah data SPSS.21 Tabel Coefficients ${ }^{a}$

Hasil persamaan regresi sebagai berikut :

\section{Keterangan:}

$$
\mathbf{Y}=\mathbf{a}+\mathbf{b}_{1} . X_{1}+\mathbf{b}_{2} \mathbf{X}_{2}+\mathbf{b}_{3} . X_{3}+e
$$

$\mathrm{Y}=$ Kinerja Guru

$\mathrm{a}=$ Konstanta

$\mathrm{b}=$ Koefisien regresi

$\mathrm{X}_{1}=$ Kualifikasi Pendidikan

$\mathrm{X}_{2}=$ Pengalaman Kerja

$\mathrm{X}_{3}=$ Disiplin Kerja

$\mathrm{e}=$ Standar error 


\section{$\mathrm{Y}=21.811+0.540 . \mathrm{X} 1+0.166 . \mathrm{X} 2+0.080 \mathrm{X3}+\mathrm{e}$}

Persamaan regresi untuk memperlihatkan hubungan antara variabel independent dengan variabel dependent secara parsial atau sendiri-sendiri, dari persamaan yang kita peroleh diatas maka dapat diambil kesimpulan sebagai berikut.

a) Nilai constanta adalah 21.811 artinya jika tidak terjadi perubahan variabel kualifikasi pendidikan, pengalaman kerja dan disiplin kerja (nilai $\mathrm{X}_{1}, \mathrm{X}_{2}$ dan $\mathrm{X}_{3}$ adalah 0) maka kinerja guru pada SMA Frater Makassar adalah sebesar 21.811.

b) Nilai koefisien kualifikasi pendidikan adalah 0.540, artinya jika variabel kualifikasi pendidikan $\left(\mathrm{X}_{1}\right)$ meningkat $1 \%$ dengan asumsi variabel pengalaman kerja $\left(\mathrm{X}_{2}\right)$, disiplin kerja $\left(\mathrm{X}_{3}\right)$ dan konstanta (a) adalah 0 (nol), maka kinerja guru pada SMA Frater meningkat sebesar 54.\%. Hal tersebut menunjukkan bahwa variabel kualifikasi pendidikan yang diterapkan berkontribusi positif bagi kinerja guru, sehingga semakin baik kualifikasi pendidikan guru maka akan semakin meningkat pula kinerja guru pada SMA Frater Makassar. c) Nilai koefisien pengalaman kerja adalah sebesar 0.166, artinya jika variabel pengalaman kerja $\left(\mathrm{X}_{2}\right)$ meningkat $1 \%$ dengan asumsi variabel kualifikasi pendidikan $\left(\mathrm{X}_{1}\right)$, disiplin kerja $\left(\mathrm{X}_{3}\right)$ dan konstanta (a) adalah 0 (nol), maka kinerja guru pada SMA Frater meningkat sebesar $16.6 \%$. Hal tersebut menunjukkan bahwa pengalaman kerja yang dimiliki guru berkontibusi positif bagi kinerja guru, sehingga semakin baik pengalaman kerja yang dimiliki setiap guru maka akan semakin meningkat pula kinerja guru pada SMA Frater Makassar.

d) Nilai koefisien disiplin kerja adalah sebesar 0.080 , artinya jika variabel disiplin kerja $\left(\mathrm{X}_{3}\right)$ meningkat $1 \%$ dengan asumsi variabel kualifikasi pendidikan $\left(\mathrm{X}_{1}\right)$, pengalaman kerja $\left(\mathrm{X}_{2}\right)$ dan konstanta (a) adalah 0 (nol), maka kinerja guru pada SMA Frater meningkat sebesar 8\%. Hal tersebut menunjukkan bahwa pengalaman kerja yang dimiliki guru berkontibusi positif bagi kinerja guru, sehingga semakin baik disiplin kerja yang dimiliki setiap guru maka semakin baik pula kinerja guru pada SMA Frater Makassar.

- Uji T-Parsial

Tabel. 2 Uji-T Parsial

\begin{tabular}{lcc}
\hline Variabel & Nilai T-Hitung & Nilai Sig-Hitung \\
\hline Kinerja Guru & 1.301 & .201 \\
Kualifikasi Pendidikan & 3.067 & .004 \\
Pengalaman Kerja & 1.453 & .155 \\
Disiplin Kerja & .637 & .528 \\
\hline
\end{tabular}

Sumber: Hasil olah data SPSS.21 Tabel Coefficients ${ }^{a}$

Berdasarkan hasil output SPSS.21 diatas diketahui bahwa nilai T-tabel untuk variabel kualifikasi pendidikan $\left(\mathrm{X}_{1}\right)$ nilai T-hitung 3.067 $>$ nilai T-tabel yaitu 2.0261 maka dapat disimpulkan bahwa variabel kualifikasi pendidikan $\left(\mathrm{X}_{1}\right)$ secara parsial berpengaruh signifikan terhadap variabel kinerja guru $(\mathrm{Y})$. Untuk variabel pengalaman kerja $\left(\mathrm{X}_{2}\right)$ nilai $\mathrm{T}$ hitung 1.453 < nilai T-tabel yaitu 2.0261 maka dapat disimpulkan bahwa variabel pengalaman kerja $\left(X_{2}\right)$ secara parsial berpengaruh tetapi tidak signifikan terhadap variabel kinerja guru $(\mathrm{Y})$. Dan untuk variabel disiplin kerja $\left(\mathrm{X}_{3}\right)$ nilai $\mathrm{T}$ - hitung 0.637 < nilai T-tabel yaitu 2.0261 maka dapat disimpulkan bahwa variabel disiplin kerja secara parsial berpengaruh tetapi tidak signifikan terhadap variabel kinerja guru $(\mathrm{Y})$.

Berdasarkan data diatas maka dapat kita simpulkan bahwa kualifikasi pendidikan $\left(\mathrm{X}_{1}\right)$ secara parsial berpengaruh signifikan terhadap variabel kinerja guru (Y). Sedangkan untuk variabel $\left(\mathrm{X}_{2}\right)$ dan $\left(\mathrm{X}_{3}\right)$ secara parsial berpengaruh tetapi tidak signifikan terhadap variabel kinerja guru (Y), yang dapat diketahui dengan membandingkan nilai t-hitung dengan nilai $t$ tabel pada output SPSS.21 hasil Uji-T. 
- Uji-F

Berdasarkan output SPSS.21 diketahui bahwa nilai Sig. yaitu $0.04<$ dari nilai probilitas 0.05 , maka berdasarkan pada dasar pengambilan keputusan maka dapat disimpulkan bahwa variabel Kualifikasi Pendidikan $\left(\mathrm{X}_{1}\right)$ dan Pengalaman Kerja $\left(\mathrm{X}_{2}\right)$ dan Disiplin Kerja $\left(\mathrm{X}_{3}\right)$ secara simultan atau bersama-sama berpengaruh terhadap variabel Kinerja Guru (Y).

Dasar pengambilan keputusan Uji-F juga dapat dilakukan berdasarkan nilai F-hitung dan nilai F-tabel. Menurut V. Wiratna Sujarweni (2014: 154), jika nilai F-hitung > F-tabel maka artinya variabel independent $(\mathrm{X})$ secara simultan berpengaruh terhadap variabel dependen $(\mathrm{Y})$.

Tabel. 3 Uji-F (ANOVA $\left.{ }^{a}\right)$

\begin{tabular}{lrrrrr}
\hline Model & Sum of Squares & df & Mean Square & F & \multicolumn{1}{l}{ Sig. } \\
\hline Regression & 91.070 & 3 & 30.357 & $\mathbf{5 . 2 5 1}$ & $\mathbf{. 0 0 4}^{\mathbf{b}}$ \\
Residual & 213.906 & 37 & 5.781 & & \\
Total & 304.976 & 40 & & & \\
\hline
\end{tabular}

a. Dependent variable: kinerja guru

b. Predictors: (constant), disiplin kerja, kualifikasi pendidikan, pengalaman kerja

Diketahui nilai F-tabel sebesar 2.85, karena nilai F-hitung 5.251 > F-tabel 2.85 maka dapat dismpulkan bahwa Kualifikasi Pendidikan
$\left(\mathrm{X}_{1}\right)$ Pengalaman Kerja $\left(\mathrm{X}_{2}\right)$ dan Disiplin Kerja $\left(\mathrm{X}_{3}\right)$ secara simultan atau bersama-sama berpengaruh terhadap variabel Kinerja Guru (Y).

Uji Delta Koefisien Determinasi

Tabel. 12 Uji Delta Koefisien Determinasi

\begin{tabular}{cccc}
\hline Nilai R & Nilai R-Square & Nilai Adjusted R-Square & Std. Error of the Estimate \\
\hline $.546^{\mathrm{a}}$ & .299 & $\mathbf{. 2 4 2}$ & 2.404 \\
\hline
\end{tabular}

Sumber: Hasil olah data SPSS.21 Tabel Model Summary ${ }^{b}$

Untuk mengetahui berapa persen pengaruh yang diberikan oleh variabel bebas kepada variabel terikat adalah dengan melihat pada tabel uji delta koefisien determinasi, yaitu nilai kolom Adjusted $R$-Square, diketahi bahwa nilai R-Square sebesar 0.242, maka dapat disimpulkan bahwa besarnya pengaruh yang diberikan variabel bebas terhadap vairabel terikat adalah $24.4 \%(0.5242 \times 100=24.4)$.

Hal ini berarti kemampuan variabel bebas dalam menjelaskan variabel terikat adalah sebesar $24.4 \%$ sisanya $75.8 \%$ dijelaskan atau dipengaruhi oleh variabel lain yang tidak dipilih dalam penelitian ini.

\section{Pembahasan}

1. Hubungan Pengaruh Kualifikasi Pendidikan, Pengalaman Kerja dan Disiplin Kerja Terhadap Kinerja Guru.

Berdasarkan hasil uji korelasi spearman diketahui bahwa nilai korelasi antara kualifikasi pendidikan dengan kinerja guru adalah 0.739. Jika melihat tabel inteprestasi korelasi milik
Sugiyono (2014), maka nilai 0.739 tersebut berada pada kategori memiliki tingkat hubungan yang kuat, karena koefisien variabel kualifikasi pendidikan berada pada interval 0,60-0,799. Maka dapat disimpulkan terdapat hubungan antara variabel kualifikasi pendidikan dengan kinerja guru, tanda positif bermakna, bahwa hubungan keduanya bersifat berbanding lurus, artinya jika variabel kualifikasi pendidikan meningkat atau naik maka variabel kinerja guru juga ikut meningkat atau naik.

Hasil tersebut juga diperkuat dengan pendapat milik Sudarwan Danim yang mengatakan bahwa salah satu faktor yang dapat mempengaruhi kinerja guru adalah tingkat pendidikan tenaga pengajar (guru), sebab kemampuan seseorang sangat dipengaruhi oeh tingkat pendidikannya. Semakin baik dan tinggi tingkat pendidikan seseorang maka semakin banyak pengetahuan dan keterampilan yang dimilikinya sehingga besar kemungkinan kinerja akan jauh lebih baik karena dibekali dengan pengetahuan dan keterampilan yang telah diperolehnya. 
Fakta yang terjadi adalah banyak guru yang telah mendekati usia pensiun, sehingga tidak dapat melaksanakan tugas dengan maksimal. Selain faktor usia, faktor lingkungan pun ikut mempengaruhi. Kepala sekolah di suatu lembaga berperan penting untuk mendorong jajaran guru agar terus meningkatkan kompetensinya. Sebab, tingkat pendidikan yang dimiliki harus terus didukung dengan aktif mengikuti seminar-seminar pendidikan, diklat, dan kursus-kursus singkat.

Hal ini juga untuk mengikuti perkembangan zaman dan teknologi. Guru dituntut untuk mampu mengoperasikan berbagai macam teknologi pendidikan yang berkaitan dengan media pembelajaran agar ilmu yang guru dapatkan ketika dibangku kuliah dapat berkembang. Tingkat keilmuan guru yang meningkat secara signifikan mampu meningkatkan kinerja guru tersebut.

Hasil penelitian yang diperoleh juga diperkuat oleh pendapat dari Kasmir bahwa salah satu faktor yang dapat mempengaruhi kinerja guru adalah disiplin kerja, sebab seorang guru yang memiliki disiplin kerja yang baik, pasti akan berusaha dengan sungguh-sungguh saat melaksanakan pekerjaannya. Segala pekerjaan dan tugas yang diberikan kepadanya akan dilaksanakan sesuai dengan aturan dan ketentuan yang telah diperintakan kepadanya.

2. Pengaruh Kualifikasi Pendidikan, Pengalaman Kerja dan Disiplin Kerja Secara Parsial Terhadap Kinerja Guru.

Hipotesis kedua dalam penelitian ini adalah diasumsikan bahwa terdapat pengaruh antara Kualifikasi Pendidikan, Pengalaman Kerja dan Disiplin Kerja Secara Parsial Terhadap Kinerja Guru.

Pertama adalah untuk membuktikan bahwa Variabel Kualifikasi Pendidikan $\left(\mathrm{X}_{1}\right)$ berpengaruh secara parsial terhadap Kinerja Guru (Y). Berdasarkan hasil penelitian yang diperoleh diketahui bahwa kontribusi atau sumbangan yang diberikan oleh variabel Kualifikasi Pendidikan $\left(\mathrm{X}_{1}\right)$ adalah sebesar 54\% terhadap Kinerja Guru (Y) SMA Frater Makassar.

Hasil tersebut memberikan kita pemahaman bahwa kualifikasi pendidikan dapat berdampak positif terhadap kinerja guru, hal ini terbukti dari indikator pendidikan formal, informal dan non formal yang telah dilakukan oleh guru SMA Frater Makassar. Mayoritas guru berasumsi bahwa kualifikasi pendidikan dapat menunjang kinerja guru SMA Frater, guru-guru yang berperan sebagai tenaga pendidik memiliki kualifikasi pendidikan yang sesuai dengan aturan yang ada, tidak hanya itu tenaga pendidik selalu berusaha mengikuti setiap pelatihan yang ada demi meningkatkan kemampuannya dalam memberikan pembelajaran kepada murid-murid SMA Frater Makassar. Tidak hanya itu saja bentuk kerja sama dan hubungan yang ada diantara guru-guru SMA Frater juga menjadi salah satu faktor yang dapat mempengaruhi kinerja guru, jika kerja sama tercipta dengan baik para guru dapat saling membantu untuk menghadapi masalah yang ada dan mampu meningkatkan kualitas kinerjanya dalam memberikan pembelajaran.

Dengan demikian dapat disimpulkan bahwa kualifikasi pendidikan berpengaruh secara parsial terhadap kinerja guru pada SMA Frater Makassar, semakin tinggi kualifikasi pendidikan guru maka kinerja guru juga akan ikut meningkat.

Kedua adalah untuk membuktikan bahwa Variabel Pengalaman Kerja $\left(\mathrm{X}_{2}\right)$ berpengaruh secara parsial terhadap Kinerja Guru (Y). Berdasarkan hasil penelitian yang diperoleh diketahui bahwa kontribusi atau sumbangan yang diberikan oleh variabel Pengalaman Kerja $\left(\mathrm{X}_{2}\right)$ adalah sebesar $16.6 \%$ terhadap Kinerja Guru (Y) SMA Frater Makassar.

Hasil tersebut memberikan kita gambaran bahwa pengalaman kerja memberikan dampak positif untuk kinerja guru hal ini dapat dilihat dari indikator dari pendidikan dan latihan yang diperoleh guru, masa mengajar atau lama mengajar serta kesempatan kerja yang dimiliki guru SMA Frater. Bagi guru pengalaman kerja merupakan hal penting yang dimiliki setiap guru, sebab dengan pengalaman kerja yang memadai maka seorang guru mampu memberikan hasil yang lebih maksimal atau kinerja yang lebih baik.

Dengan demikian dapat disimpulkan bahwa pengalaman kerja berpengaruh secara parsial terhadap kinerja guru pada SMA Frater Makassar, semakin tinggi pengalaman kerja maka kinerja guru juga akan ikut meningkat. Namun pada lokasi penelitian di SMA Frater Makassar variabel pengalaman kerja berpengaruh secara parsial namun tidak signifikan terhadap variabel kinerja guru, ini terjadi dimungkinkan karena sebagian guru merasa jenuh dengan pekerjaannya. 
Ketiga adalah untuk membuktikan bahwa variabel Disiplin Kerja $\left(\mathrm{X}_{3}\right)$ berpengaruh secara parsial terhadap Kinerja Guru (Y). Berdasarkan hasil penelitian yang diperoleh diketahui bahwa kontribusi atau sumbangan yang diberikan oleh variabel Disiplin Kerja $\left(\mathrm{X}_{3}\right)$ adalah sebesar 8\% terhadap Kinerja Guru (Y) SMA Frater Makassar.

Hasil tersebut memberikan kita pemahaman bahwa disiplin kerja memberikan dampak positif terhadap kinerja guru, hal ini dapat dilihat dari indikator-indikator disiplin kerja yaitu teladan pimpinan, balas jasa, keadilan, ketegasan dan hubungan kemanusiaan yang berada pada kategori sangat baik. Pada SMA Frater Makassar para guru menganggap bahwa telah memiliki sosok sikap teladan pimpinan yang baik sehingga hal tersebut menjadi faktor yang dapat mempengaruhi kinerjanya, sebab para guru menjadi lebih termotivasi karena melihat sosok pimpinan yang baik, tidak hanya itu bentuk balas jasa yang diterima guru dianggap cukup dan mampu memenuhi kebutuhan para guru, apa yang telah dilakukan atau dikerjakan dianggap sesuai dengan balas jasa yang diterima.

Disiplin kerja merupakan salah satu faktor yang dapat mempengaruhi kinerja seorang guru, sebab seseorang yang memiliki disiplin kerja yang baik akan selalu berusaha melaksanakan setiap pekerjaannya berdasarkan aturan yang telah ada.

Disiplin kerja merupakan hal yang sangat penting dalam upaya meningkatkan kinerja guru, karena kedisiplinan merupakan bagian yang tak terpisahkan dalam melaksanakan tugas dan kewajiban sebagai guru.

Namun pada lokasi penelitian SMA Frater Makassar variabel disiplin kerja berpengaruh namun tidak signifikan terhadap kinerja guru. Oleh sebab itu disarankan agar sikap tegas kepala sekolah ditingkatkan lagi sehingga guru-guru akan lebih termotivasi dan menjadi lebih disiplin.

3. Pengaruh Kualifikasi Pendidikan, Pengalaman Kerja dan Disiplin Kerja Secara Simultan atau Bersama-sama Terhadap Kinerja Guru.

Berdasarkan hasil penelitian yang telah dilakukan melalui olah data SPSS, diperoleh output pada uji-f yaitu nilai F-tabel untuk $\mathrm{N}=41$ sebesar 2.85, karena nilai F-hitung 5.251 > Ftabel 2.85 maka dapat disimpulkan bahwa variabel Kualifikasi Pendidikan $\left(\mathrm{X}_{1}\right)$, Pengalaman Kerja $\left(\mathrm{X}_{2}\right)$ dan Disiplin Kerja $\left(\mathrm{X}_{3}\right)$ secara simultan atau bersama-sama berpengaruh terhadap variabel Kinerja Guru (Y).

Hasil olah data pada tabel Model Summary menunjukkan bahwa pada kolom Adjusted R Square, diketahi nilai Adjusted R Square sebesar 0.242 , yang berarti bahwa besarnya pengaruh yang diberikan oleh variabel kualifikasi pendidikan, pengalaman kerja dan disiplin kerja terhadap kinerja guru adalah $24.2 \%$. Hal ini berarti kemampuan variabel bebas dalam menjelaskan variabel terikat adalah sebesar $24.2 \%$ sisanya $75.8 \%$ dijelaskan atau dipengaruhi oleh variabel lain yang tidak dipilih dalam penelitian ini.

Kinerja guru dapat ditingkatkan dengan disiplin kerja yang baik. tindakan disiplin jika dilakukan secara terus menerus akan menjadi kebiasaan yang tertanam dalam perilaku guru. Penerapan disiplin yang baik dalam proses pendidikan akan menghasilkan sikap mental, watak dan kepribadian yang baik.

Pengalaman kerja seorang guru juga dapat mempengaruhi kinerja guru, dengan pengalaman kerja yang baik seorang guru mampu mengambil keputusan yang tepat jika dihadapkan pada situasi tertentu, tidak hanya itu pengalaman juga sangat bermanfaat untuk meningkat keahlian dan kompetensi seorang guru dalam memberikan pembelajaran kepada murid-murid.

Faktor ketiga yang dapat mempengaruhi kinerja guru adalah bahwa kualifikasi pendidikan juga memliki pengaruh positif terhadap kinerja guru, kesesuaian kompetensi dan jenjang pendidikan yang dimiliki sangat penting untuk menunjang pekerjaan seorang guru, sebab jika seorang guru diberikan tugas yang sesuai dengan keahliannya maka ia akan mampu menjelaskan dengan baik karena telah memiliki komptensi dan keahlian yang sesuai untuk melaksanakan tugas atau pekerjaan tersebut.

Senada dengan pendapat yang disampaikan oleh Ahmad Barizi (2009: 142) yang mengatakan bahwa latar belakang pendidikan dan pengalaman mengajar merupakan dua aspek yang dapat mempengaruhi profesionalisme seorang guru dalam bidang pendidikan dan pengajaran. Sedangkan Menurut (Kasmir, 2017) mengatakan bahwa salah satu faktor yang dapat mempengaruhi kinerja baik hasil ataupun perilaku kinerja adalah disiplin kerja. Dengan demilikian dapat kita simpulkan bahwa kualifikasi pendidikan, pengalaman kerja 
dan disiplin kerja berpengaruh secara simultan atau bersama-sama terhadap kinerja guru.

\section{KESIMPULAN DAN SARAN}

\section{Kesimpulan}

Berdasarkan hasil penelitian dan pembahasan, maka dapat ditarik beberapa kesimpulan sebagai berikut:

1. Variabel kualifikasi pendidikan pada SMA Frater Makassar yang diukur berdasarkan indikator pendidikan formal, informal dan non formal berada pada kategori baik dengan pencapaian presentase sebesar $86.951 \%$.

2. Variabel pengalaman kerja pada SMA Frater Makassar yang diukur berdasarkan indikator pendidikan dan pelatihan, masa mengajar atau lama mengajar serta kesempatan kerja berada pada kategori cukup baik dengan pencapaian presentase presentase sebesar $67.357 \%$.

3. Variabel disiplin kerja pada SMA Frater Makassar yang diukur berdasarkan indikator teladan pimpinan, balas jasa, keadilan, ketegasan, dan hubungan atau kemanusiaan berada pada kategori sangat baik dengan pencapaian presentase sebesar $87.956 \%$.

4. Variabel kinerja guru pada SMA Frater Makassar yang diukur berdasarkan indikator perencanaan dan pelaksanaan pembelajaran serta kemampuan bekerja sama berada pada kategori sangat baik dengan pencapaian presentase sebesar $89.3 \%$.

5. Terdapat pengaruh positif dan signifikan secara parsial antara kualifikasi pendidikan terhadap kinerja guru SMA Frater Makassar, besarnya pengaruh yang diberikan oleh variabel kualifikasi pendidikan terhadap kinerja guru adalah $54 \%$, sedangkan untuk hasil uji korelasi dapat disimpulkan bahwa tingkat hubungan kualifikasi pendidikan terhadap kinerja guru berada tingkat kategori kuat dengan nilai-r 0.739 karena koefisen variabel kualifikasi pendidikan berada pada interval 0,60-0,799.

6. Terdapat pengaruh positif tapi tidak signifikan secara parsial antara pengalaman kerja terhadap kinerja guru SMA Frater Makassar, besarnya pengaruh yang diberikan oleh variabel pengalaman kerja terhadap kinerja guru adalah $16.1 \%$, sedangkan untuk hasil uji korelasi dapat disimpulkan bahwa tingkat hubungan pengalaman kerja terhadap kinerja guru berada pada tingkat kategori kuat, dengan nilai-r 0.655 .
7. Terdapat pengaruh positif tapi tidak signifikan secara parsial antara disiplin kerja terhadap kinerja guru SMA Frater Makassar, besarnya pengaruh yang diberikan oleh variabel pengalaman kerja terhadap kinerja guru adalah $8 \%$ sedangkan untuk hasil uji korelasi dapat disimpulkan bahwa tingkat hubungan kualifikasi pendidikan terhadap kinerja guru berada pada tingkat kategori kuat, dengan nilai-r 0.757 .

8. Terdapat pengaruh positif dan signifikan antara kualifikasi pendidikan, pengalaman kerja dan disiplin kerja secara bersama-sama atau simultan terhadap kinerja guru pada SMA Frater Makassar, besarnya kontribusi pengaruh yang diberikan oleh ketiga variabel tersebut adalah 24.2.\%.

\section{Saran}

Berdasarkan hasil penelitian, pembahasan dan kesimpulan yang telah diperoleh, maka saran yang dapat diberikan adalah sebagai berikut.

1. Faktor kualifikasi pendidikan, pengalaman kerja dan disiplin kerja merupakan faktor yang dapat mempengaruhi kinerja guru, oleh sebab itu disarankan kepada guru-guru untuk meningkatkan kinerjanya dengan melanjutkan pendidikan yang lebih tinggi, aktif mengikuti pelatihan dengan sungguhsungguh dan selalu disipilin dalam bekerja.

2. Peningkatan kinerja guru perlu didukung oleh motivasi dari pengawas agar guru dapat menerapkan pengetahuan dan ilmu yang dikuasai dengan baik sehingga dapat menjalankan tugas sebagai pendidik dengan baik dan professional.

3. Penelitian ini memberikan informasi bahwa kualifikasi pendidikan, pengalaman kerja dan disiplin kerja mempunyai pengaruh terhadap kinerja guru. Untuk itu, perlu adanya penelitian lebih lanjut terhadap faktor-faktor yang dapat meningkatkan kinerja guru terlepas dari tiga faktor yang telah dibahas dalam penelitian ini.

\section{DAFTAR PUSTAKA}

Ahmadi, Rulam. 2017. Pengantar Pendidikan Asas dan Filsafat Pendidikan. Yogyakarta: Ar-ruzz Media, Inferensi, dan NonParametrik. Jakarta: KENCANA.

Andi Supangat. 2007. STATISTIKA: Dalam kajian Deskriptif

Arif Yusuf Hamali. 2018. Pemahaman 
Manajemen Sumber Daya Manusia. Jakarta: CAPS.

Arnianti. 2018. Analisis Pendidikan Informal Keluarga Petani Jagung Kaitannya Dengan Keinginan Menyekolahkan Anak. Tesis. Tidak diterbitkan.Makassar: Program Pascasarjana Universitas Negeri Makassar. 1

Bintoro, Daryanto. 2017. Manajemen Penilaian Kinerja Karyawan. Yogyakarta: Penerbit Gava Media.

Iqbal Hasan. Edisi kedua. Pokok - Pokok Materi Statistik 2 (Statistik Inferensif). Jakarta: PT Bumi Aksara.

Kasmir. 2018. Manajemen Sumber Daya Manusia (Teori dan Praktik). Depok: PT Rajagrafindo Persada.

Kunandar.2014. Guru Profesional Implementasi Kurikulum Tingkat Satuan Pendidikan (KTSP) dan Sukses dalam Sertifikasi Guru Edisi Revisi. Jakarta: PT Rajagrafindo Persada.

Matturungan, Nur Hasbullah., Kurniawati, Ria \& Sukmawati, Anggraini. 2016. Pengaruh Learning Organization, Kualifikasi Pendidikan, dan Pengalaman Kerja Terhadap Peningkatan Kinerja Karyawan di Balai Penelitian dan Pengembangan Sumber Daya Lahan Pertanian (BBSDLP) Bogor Khususnya di Bidang Pelayanan Publik. Jurnal Aplikasi Manajemen Departemen Manajemen, Fakultas Ekonomi dan Manajemen Institut Pertanian Bogor, 14(2), ISSN: 16935241, 267-271.

Ningrum, Epon, 2001. Profesionalitas Guru. Jakarta: Rineka Cipta.

Supardi. 2016. Kinerja Guru. Jakarta: PT Rajagrafindo Persada.

Sutirna \& Samsudin, Asep. 2015. Landasan Kependidikan (Teori dan Praktik). Bandung: PT. Refika Aditama.

Undang-UndangGuru dan Dosen. 2005. Undang-Undang Republik Indonesia Nomor 14 Tahun 2005 tentang Guru dan Dosen. Jakarta: Sekretariat Negara Republik Indonesia.

Undang-UndangSistem Pendidikan Nasional. 2003. Undang-Undang Republik Indonesia Nomor 20 Tahun 2003 tentang Sistem Pendidikan Nasional. Jakarta: Sekretariat Negara Republik Indonesia. Undang-

UndangStandarNasionalPendidikan.2005. Peraturan Pemerintah Republik Indonesia
Nomor 19 Tahun 2005 tentangStandar Nasional Pendidikan.Jakarta: Departemen Pendidikan dan Kebudayaan.

Foster, Bill. 2001. Pembinaan untuk Peningkatan Kinerja Karyawan. PPM: Jakarta.

Gunawan, Iba \& Riza, Muhamad. 2019. Pengaruh Tingkat Pendidikan Terhadap Prestasi Kerja Karyawan (Studi pada PT. Indonesia Power Unit Pembangkit Surabaya Cilegon). Jurnal Pendidikan, Akuntansi dan Keuangan Universitas Banten Jaya, 2(1), ISSN: 2622-7037, 4756.

Hadiati, Eti. 2018. Pengaruh Disiplin Kerja Terhadap Kinerja Guru MTs Se-Kota Bandar Lampung.Al-Idarah: Jurnal Kependidikan Islam, 8 (1), ISSN: 25802453, 50-65.

Hasibuan.Edisi revisi. Manajemen Sumber Daya Manusia. Jakarta. PT Bumi Aksar

Pujiyanti \& Isroah.2012.Pengaruh Motivasi Kerja dan Disiplin Kerja Terhadap Kinerja Guru SMA Negeri 1 Ciamis.Kajian Pendidikan Akuntansi Indonesia, 184-207.

Reski. 2016. Pengaruh Kualifikasi Pendidikan, Pengalaman Kerja, dan Disiplin Kerja Terhadap Peningkatan Prestasi Kerja Guru di SMP Negeri 1 Tompobulu Kabupaten Bantaeng. Tesis. Tidak diterbitkan.Makassar: Program Pascasarjana Universitas Negeri Makassar.

Rofi, Ahmad Nur. 2012. Pengaruh Disiplin Kerja Dan Pengalaman Kerja Terhadap Prestasi Kerja Karyawan pada Departemen Produksi PT. Leo Agung Raya Semarang. Jurnal Ilmu Manajemen dan Akuntnsi Terapan Sekolah Tinggi Ilmu Ekonomi Totalwin Semarang, 3(1), 1-21.

Sinambela Poltak Lijan. 2018. Manajemen Sumber Daya Manusia: membangun tim kerja yang solid olid untuk meningkatkan kinerja. Jakarta. PT Bumi Aksara

Sinambela Poltak Lijan. 2019. Manajemen Sumber Daya Manusia: membangun tim kerja yang solid olid untuk meningkatkan kinerja. Jakarta. PT Bumi Aksar

Siregar, Fauziyah Novia Khoirunnisa\&Thomas, Partono. 2015. Pengaruh Disiplin Kerja dan Iklim Kerja Terhadap Kinerja Guru Ekonomi/Akuntansi Di SMA Negeri SeKabupaten Wonosobo. Economic Education Analysis Journal, 4(1), ISSN: 2252-6544, 172-177. 
Sutrisno Edy. 2009. Manajemen Sumber Daya Manusia. Jakarta. Kencana.

Sutrisno Edy. 2010. Budaya Organisasi. Jakarta. Prenada Media Group.

Sujana , Nana, 1998. Dasar - Dasar Proses Belajar Mengajar. Bandung: Sinar Baru Algesindo.
Suyatno.(2008). Panduan Sertifikasi Guru. Jakarta: Indeks.

Wahid Sulaiman. (2005). Statistik Non Parametrik Contoh Kasus dan Pemecahannya dengan SPSS. Yogyakarta: ANDI OFFSET. 